\title{
Analisis Video Likes To Video Views Ratio Instagram Pada 5 Selebgram Perempuan Di Dunia Dengan Bayaran Tertinggi
}

\author{
Sunardin \\ Sunardin0201@gmail.com
}

\begin{abstract}
Instagram comes from the word "instant" or "insta", Instagram can also display photos instantly in its display. As for the word "gram" comes from the word "telegram", where the way the telegram works is to send information to other people quickly. In Indonesia, the number of Instagram users until July 2021 is 91.77 million users. The largest users are in the 18-24 year age group, which is $36.4 \%$. The emergence of Instagram social media is now increasingly booming, and many unknown people appear on the screen. But they are very well known on Instagram, so they are called Celebgrams. The Instagram Accounts of the 5 Highest Paid Female Celebrities in the World, namely: Kenddell Jenner, Selena Gomez, Kylie Jenner, Khole Kardashian, Priyanka Copra Jonas. The purpose of this study is to calculate from the performance of the Instagram accounts of the 5 Highest Paid Female Celebrities in the World. The method used for this research is exploratory quantitative method. The results of this study indicate that Kylie Jenner is ranked first and has a good account performance.
\end{abstract}

\begin{abstract}
ABSTRAK
Instagram berasal dari kata "instan" atau "insta", Instagram juga dapat menampilkan foto-foto secara instan dalam tampilannya. Sedangkan untuk kata "gram" berasal dari kata "telegram", dimana cara kerja telegram adalah untuk mengirimkan informasi kepada orang lain dengan cepat. Di Indonesia, jumlah pengguna Instagram hingga Juli 2021 sebesar 91,77 juta pengguna. Pengguna terbesar terdapat di kelompok usia 18 - 24 tahun yaitu 36,4\%. Kemunculan media sosial Instagram kini semakin booming, dan banyak bermunculan orang-orang yang tidak dikenal di layar kaca. Namun sangat dikenal di Instagram, Sehingga mereka itulah yang disebut sebagai Selebgram. Adapun Akun Instagram dari 5 Selebgram Perempuan di Dunia Dengan Bayaran Tertinggi, yaitu : Kenddell Jenner, Selena Gomez, Kylie Jenner, Khole Kardashian, Priyanka Copra Jonas. Tujuan dari penelitian ini yaitu untuk menghitung kredibilitas dari performa akun Instagram 5 Selebgram Perempuan di Dunia Dengan Bayaran Tertinggi. Metode yang digunakan untuk penelitian ini yaitu metode eksploratif kuantitatif. Hasil dari penelitian ini menunjukan bahwa Kylie Jenner mendapatkan peringkat pertama dan memiliki kredibilitas performa akun yang baik.
\end{abstract}

Keyword : Credibility Account Instagram ; Social Media Marketing ; Social Media Instagram ; Video Likes to Video Views Ratio ; Selebgram Perempuan 


\section{PENDAhULUAN}

Teknologi informasi dan komunikasi yang telah berkembang dengan pesat mampu menghantarkan manusia untuk menciptakan bentuk baru dalam cara berkomunikasi serta berinteraksi melalui media sosial. Media sosial memberikan pengaruh yang cukup besar, saat ini media sosial diajadikan sarana berkomunikasi dalam setiap aktifitas keseharian bersosial di masyarakat. Komunikasi tidak hanya dapat dilakukan secara fisik, tetapi juga dapat dilakukan dengan menggunakan berbagai aplikasi media sosial di dunia maya. Keunggulan layanan aplikasi sosial media adalah memberikan ruang komunikasi dua arah antara konsumen-perusahaan dan konsumen-konsumen.

Instagram sebagai salah satu media sosial yang saat ini menjadi sebuah gaya hidup baru ditengah - tengah masyarakat khususnya dikalangan anak muda yang memakai sosial media dikehidupan sehari-harinya. Instagram merupakan sebuah aplikasi berbagi foto yang memungkinkan pengguna mengambil foto, menerapkan filter digital, dan membagikannya. Instagram berdiri pada tahun 2010 yang didirikan oleh Mike Krieger dan Kevin Systrom yang merupakan pemrogram komputer dan pengusaha internet. Kata instagram sendiri berasal dari kata insta, yang berarti instan, dan Gram yang diambil dari kata telegram (Ipa \& Di, 2017)

Pada sosial media instagram, pengguna yang memiliki banyak followers disebut dengan selebgram. Situs celebgramme.com menyebutkan, selebgram adalah istilah untuk mereka pengguna akun instagram yang terkenal di situs jejaring sosial tersebut. Istilah selebgram berasal dari kata selebriti dan instagram yang bisa berarti selebriti yang ngetop di instagram. Cukup banyak Selebgram Terkenal dengan bayaran tertinggi. contohnya Seperti 5 Perempuan di dunia dengan bayaran tertinggi, diantaranya : Kenndall Jenner, Kylie Jenner, Selena Gomez, Khole Kardashian, Priyanka Copra Jonas. (" 5 Selebgram Perempuan Di Dunia Dengan Bayaran Tertinggi”)

Penelitian ini menggunakan metode eksploratif kuantitatif, dan akan menghitung menggunakan rasio-rasio yang ada pada Instagram. terdapat 14 rasio yang ada pada sosial media Instaggram dan relevan digunakan sebagai media ukur kredibilitas akun yang ada. Penelitian ini hanya berfokus untuk menghitung kredibilitas Video Likes to Video Views pada 5 Selebgram Perempuan di Dunia Dengan Bayaran Tertinggi. Tujuan dari penelitian ini adalah mengetahui kredibilitas performa dari akun Instagram 5 Selebgram Perempuan di Dunia Dengan Bayaran Tertinggi menggunkan Video Likes to Video Views Ratio. 


\section{TINJAUAN PUSTAKA}

Perkembangan bidang teknologi saat ini terjadi begitu pesat. Melalui perkembangan yang terjadi dari waktu ke waktu menimbulkan maraknya aplikasi - aplikasi serta platform media sosial yang bermunculan. Aplikasi yang sangat diminati oleh masyarakat saat ini diantaranya adalah TikTok, Instagram, Twitter, WhatsApp dan yang lain sebagainya. Seiring berjalannya waktu, aplikasi sosial media tersebut dapat menjadi candu bagi kalangan masyarakat. Tidak hanya kalangan remaja yang menggunakan aplikasi sosial media, orang tua bahkan anak-anak juga aktif menggunakan aplikasi sosial media tersebut.

Instagram berasal dari kata "instan" atau "insta", seperti kamera polaroid yang dulu lebih dikenal dengan "foto instan" (Pengertian instagram, 2012, dalam http://.id.wikipedia.org./wiki/instagram, diakses pada tanggal 04 Januari 2016). Instagram juga dapat menampilkan foto-foto secara instan dalam tampilannya. Sedangkan untuk kata "gram" berasal dari kata "telegram", dimana cara kerja telegram adalah untuk mengirimkan informasi kepada orang lain dengan cepat. Begitu pula dengan Instagram yang dapat mengunggah foto dengan menggunakan jaringan internet, sehingga informasi yang disampaikan dapat diterima dengan cepat. Oleh karena itulah Instagram berasal dari kata "instan-telegram" (Difika, 2016)

Instagram adalah salah satu platform media sosial yang paling populer di dunia, terutama di kalangan dewasa muda. Hingga kuartal I-2021, jumlah pengguna aktif Instagram di seluruh dunia mencapai 1,07 miliar dan 354 juta penggunanya berusia 25 hingga 34 tahun. Di Indonesia, jumlah pengguna Instagram hingga Juli 2021 sebesar 91,77 juta pengguna. Pengguna terbesar terdapat di kelompok usia 18 - 24 tahun yaitu 36,4\% Instagram berada di urutan ketiga sebagai platform media sosial yang paling sering digunakan, setelah YouTube dan WhatsApp. Instagram menjadi media sosial yang sangat populer di berbagai belahan dunia karena memungkinkan penggunanya untuk berbagi konten fotografi serta mengikuti kehidupan para pesohor favorit.(Mafulla \& Kholik, n.d.)

Kemunculan media sosial Instagram kini semakin booming, dan banyak bermunculan orang-orang yang tidak dikenal di layar kaca. Namun sangat dikenal di Instagram, Sehingga mereka itulah yang disebut sebagai Selebgram. Untuk menjadi selebgram yaitu dengan memiliki banyak followers di Instagram dan harus kreatif mungkin dalam 
memposting sesuatu. Postingan yang disebarkan oleh Selebgram memang tidak gratis begitu saja. Mereka bisa mendapatkan bayaran yang cukup mahal hanya untuk sekedar memasang foto atau video bersama dengan suatu brand. Hal tersebut yang membuat makin banyak Selebgram yang sukses dan tentunya semakin kaya.(Aulia Putri 2020)

Instagram yang semakin dirasakan memiliki kekuatan ataupun pengaruh dalam industri menimbulkan yaitu kualitas akun yang menentukan strata maupun kredibilitas pemilik akun. Kredibilitas sebuah akun instagram merupakan sebuah hal yang penting untuk berbagai kepentingan. Kredibilitas dapat diukur dari peforma sebuah akun yang harus dapat diukur secara matematis. Dalam mengukur peforma diperlukan skala pengukuran yang akan tertuang dalam rasio-rasio. Skala pengukuran dibagai menjadi dua yaitu data kualitaitf dan data kuantitatif. Data kuantitatif dibagi menjadi dua yatiu; data diskrit/nominal dandata kontinum. Data kontinum dibagai menjadi tiga yaitu ordinal, interval dan ratio.

\section{METODE PENELITIAN}

Pada Penelitian ini digunakan metode eksploratif kuantitatif dalam mengetahui kredibilitas pada Performa Akun Instagram dari 5 Selebgram Perempuan di Dunia Dengan Bayaran Tertinggi. Penelitian Eksploratif merupakan studi dengan melakukan penelusuran, terutama dalam pemantapan konsep yang akan digunakan dalam ruang lingkup yang penelitian yang lebih luas dengan jangakauan konseptual yang lebih besar (Yusuf, 2017)

Tujuan dari penelitian ini adalah untuk mengetahui nilai kredibillitas dari performa akun Instagram 5 Selebgram Perempuan di Dunia Dengan Bayaran Tertinggi . beberapa langkah yang harus dilakukan dalam penelitian ini, sehingga mampu menemukan peringkat pertama dari akun Instagram Selebgram Perempuan di Dunia Dengan Bayaran Tertinggi yang memiliki performa terbaik. Langkah-langkah yang akan dilakukan pada penelitian ini, diantaranya adalah sebagai berikut :

\section{Melakukan Eksplorasi Pada Website Untuk Menentukan Objek yang Akan Dianalisa.}

Pada Eksplorasi ini dilakukan pada beberapa halaman website yang menyediakan informasi mengenai objek yang akan di teliti. Setelah eksplorasi selesai dilakukan, ditemukan beberapa nama-nama selebgram perempuan yang akan dijadikan objek analisa. Setelah melakukan eksplorasi pada halaman website, maka langkah selanjutnya yaitu mencari nama akun Instagram dari masing-masing selebgram 
perempuan. Pastikan semua selebgram tersebut memiliki akun pada aplikasi sosial media Instagram.

\section{Menghitung Nilai Rata-Rata Variabel Dari 5 Selebgram Perempuan di Dunia Dengan Bayaran Tertinggi}

Dalam langkah Ini, peneliti harus menghitung nilai Variabel Video Likes dan Variabel Video Views. Variabel adalah suatu atribut atau sifat atau nilai dari obyek atau kegiatan yang memiliki variasi tertentu yang telah ditetapkan oleh peneliti untuk dipelajari dan kemudian ditarik kesimpulannya (Sugiyono 2015). Untuk menghitung nilai rata-rata pada variabel video Likes dan variabel video views yaitu dengan cara mengambil minimal 10 postingan kemudian di hitung sehingga menemukan nilai rata-rata dari masing-masing variabel.

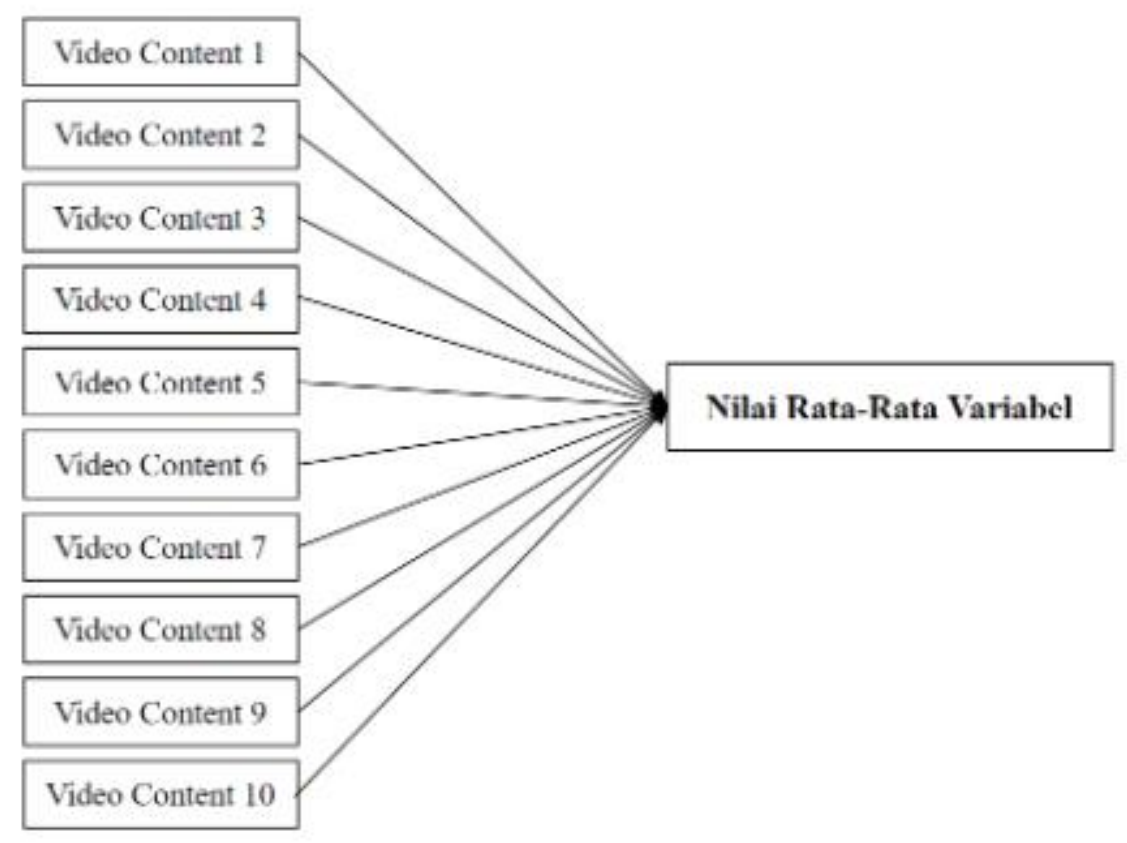

Gambar 1. Analisa Nilai Rata-Rata Variabel.

\section{Menghitung Nilai Kredibilitas Rasio}

Untuk menghitung nilai kredibilitas dari video Likes to video views ratio, peneliti menggunakan cara membagi nilai variabel pertama dengan nilai variabel kedua. 
Jika video comments memiliki nilai 200 dan video views memiliki nilai 300, maka cara menghitungnya yaitu $200: 300=0,6$. Dengan begitu nilai dari video likes to video views ratio adalah 0,6 .

\section{Menentukan Peringkat Pada Akun Instagram}

Pada langkah terakhir yang dilakukan pada penelitian ini yaitu menentukan peringkat pada masing-masing rasio yang ada. Pada penentuan peringkat perlu melihat karakteristik dari rasio yang di teliti. Jika karakteristik rasio merupakan rendah, maka objek yang memiliki nilai terendah akan mendapatkan angka 5 dan objek yang memiliki nilai tertinggi akan mendapatkan angka 1. Namun jika rasio memiliki karakteritik tinggi maka objek yang mendapatkan nilai tinggi akan mendapatkan angka 5 dan objek yang mendapatkan nilai terendah akan mendapatkan angka 1. Setelah mendapatkan hasil kredibilitas ratio maka dapat disimpulkan objek yang mana mendapatkan peringkat 1 sampai dengan peringkat 5. 


\section{HASIL DAN PEMBAHASAN}

Akun Instagram dari 5 Selebgram Perempuan di Dunia Dengan Bayaran Tertinggi, diantaranya :

\section{Kenddell Jenner}
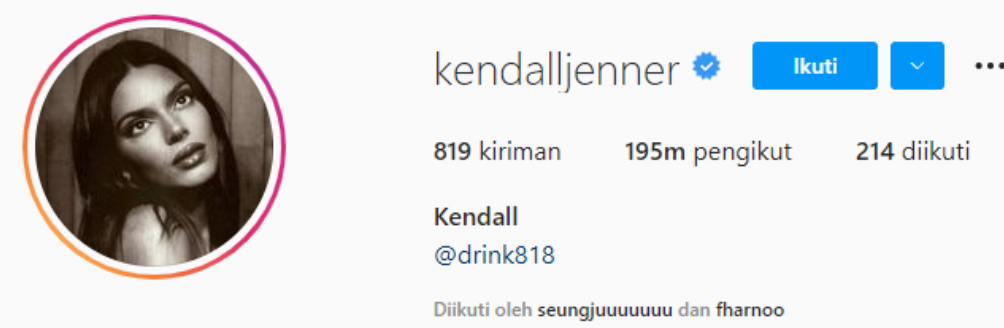

Diikuti oleh seungjuuuuuuu dan fharnoo

Gambar 1. Akun Instagram Kenddel Jenner

Sumber : https://www.instagram.com/kendalljenner/ (akses pada 20-10-2021)

\section{Selena Gomez}
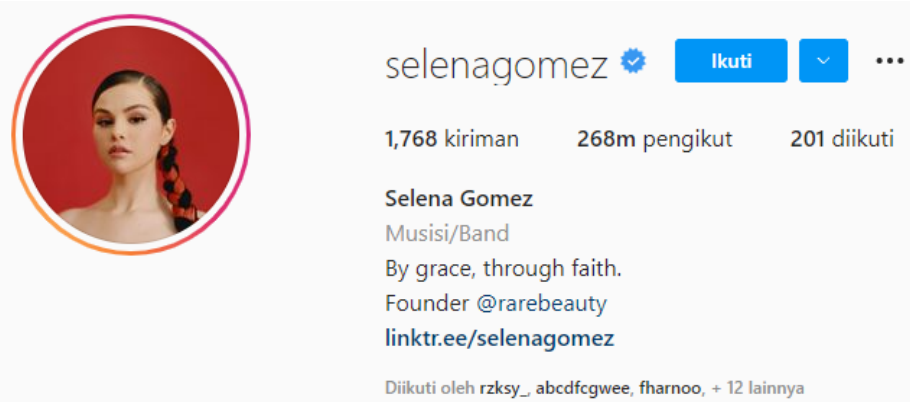

Gambar 2. Akun Instagram Selena Gomez

Sumber : https://www.instagram.com/selenagomez/ (akses pada 20-10-2021) 


\section{Kylie Jenner}
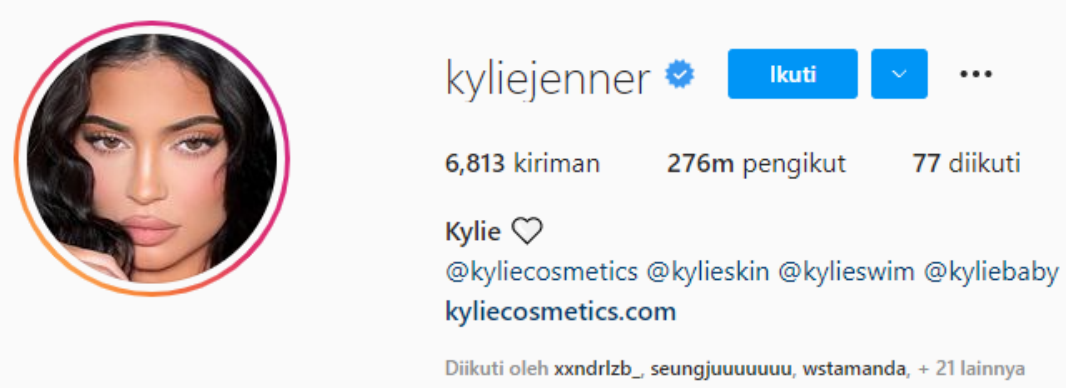

Gambar 3. Akun Instagram Kylie Jenner

Sumber : https://www.instagram.com/kyliejenner/ (akses pada 20-10-2021)

\section{Khole Kardashian}
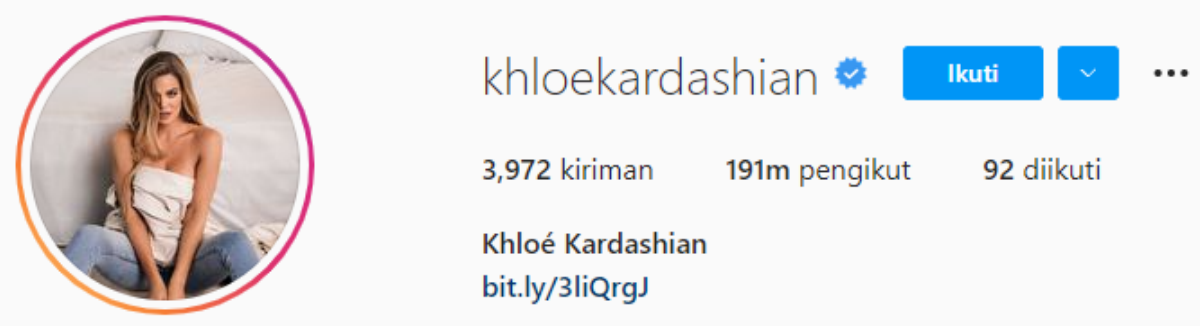

Diikuti oleh abcdfcgwee dan kelvin_lalu22

Gambar 4. Akun instagram Khole Kardasian

Sumber : https://www.instagram.com/khloekardashian/ (akses pada 20-10-2021)

\section{Priyanka Copra Jonas}
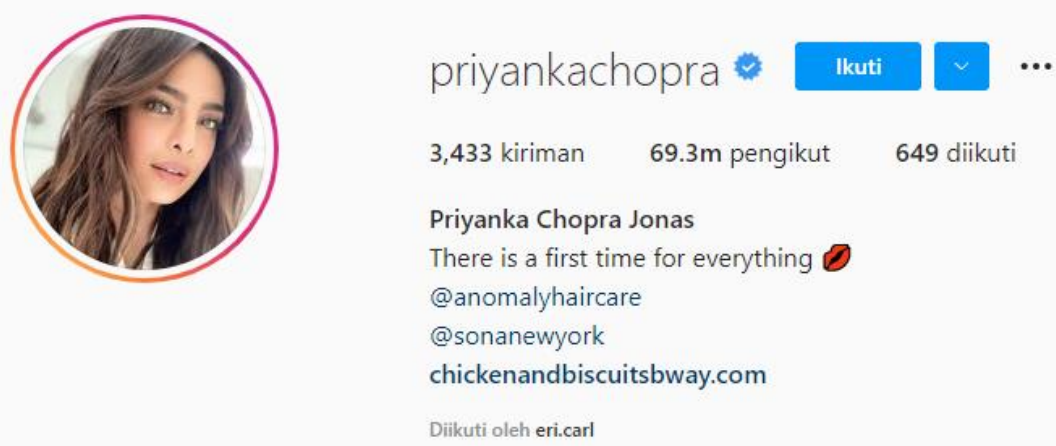
Gambar 5. Akun Instagram Priyanka Copra Jonas

Sumber : https://www.instagram.com/priyankachopra/ (akses pada 20-10-2021)

Dari kelima akun Instagram 5 Selebgram Perempuan di dunia Dengan Bayaran Tertinggi, peneliti menemukan nilai dari masing-masing variabel yang ada untuk menghitung rasio Video Likes to Video Views dari setiap akun. Pada akun Instagram terdapat 7 variabel, diantaranya yaitu :

1. Likes

2. Followers

3. Following

4. Video Likes

5. Video Comments

6. Video Share

7. Video Views

Dari ketujuh variabel tersebut peneliti hanya fokus untuk menemukan hasil dari 2 variabel, yaitu :

1. Video Likes

2. Video Views

Dari kedua variabel tersebut kemudian dianalisa sehingga menemukan nilai rata-rata dari variabel video Likes dan variabel video views. Untuk menghitung nilai rata-rata dari variabel video Likes dan variabel video views yaitu dengan cara mengambil minimal 10 postingan kemudian di hitung sehingga menemukan nilai rata-rata dari masing-masing variabel. Berikut merupakan tabel nilai rata-rata dari masing-masing Selebgram perempuan di Dunia Dengan Bayaran, yaitu : 
Tabel 1. Analisa Nilai Rata-Rata Nilai Variabel Video Likes dan Video Views Akun Instagram Kenddel Jenner

\begin{tabular}{|l|c|r|}
\hline No. & Video Likes & \multicolumn{1}{|c|}{ Video Views } \\
\hline 1 & 43.737 & 10.748 .591 \\
\hline 2 & 2.771 .290 & 17.186 .343 \\
\hline 3 & 42.353 & 2.174 .465 \\
\hline 4 & 2.012 .258 & 15.988 .182 \\
\hline 5 & 1.992 .866 & 10.704 .188 \\
\hline 6 & 4.756 .083 & 21.093 .547 \\
\hline 7 & 1.683 .278 & 11.211 .152 \\
\hline 8 & 3.237 .663 & 25.088 .870 \\
\hline 9 & 1.981 .822 & 26.120 .224 \\
\hline 10 & 1.281 .986 & 10.776 .882 \\
\hline Total & 1.980 .334 & $15.109 .244,00$ \\
\hline
\end{tabular}

Sumber : Pengolah Data Excel

Tabel 2. Analisa Nilai Rata-Rata Nilai Variabel Video Likes dan Video Views Akun Instagram Selena Gomez

\begin{tabular}{|l|c|c|}
\hline No. & Video Likes & Video Views \\
\hline 1 & 1.760 .309 & 8.729 .944 \\
\hline 2 & 1.262 .797 & 5.793 .801 \\
\hline 3 & 1.706 .041 & 8.776 .058 \\
\hline 4 & 644.794 & 28.366 .386 \\
\hline 5 & 2.817 .937 & 15.222 .295 \\
\hline 6 & 1.711 .301 & 6.056 .003 \\
\hline 7 & 1.807 .520 & 7.010 .176 \\
\hline 8 & 1.595 .235 & 6.829 .773 \\
\hline 9 & 1.338 .019 & 4.494 .175 \\
\hline 10 & 1.762 .662 & 5.322 .919 \\
\hline Total & 1.640 .662 & 9.660 .153 \\
\hline
\end{tabular}

Sumber : Pengolah Data Excel 
Tabel 3. Analisa Nilai Rata-Rata Nilai Variabel Video Likes dan Video Views Akun Instagram Kylie Jenner

\begin{tabular}{|l|l|l|}
\hline No. & Video Likes & Video Views \\
\hline 1 & 4.487 .951 & 19.119 .624 \\
\hline 2 & 3.073 .866 & 18.379 .777 \\
\hline 3 & 1.796 .120 & 9.066 .341 \\
\hline 4 & 1.441 .497 & 7.673 .622 \\
\hline 5 & 2.107 .031 & 10.862 .358 \\
\hline 6 & 3.548 .317 & 10.263 .774 \\
\hline 7 & 8.620 .616 & 45.118 .301 \\
\hline 8 & 5.486 .427 & 23.535 .175 \\
\hline 9 & 1.234 .892 & 6.590 .797 \\
\hline 10 & 6.602 .809 & 37.748 .286 \\
\hline Total & 3.839 .953 & 18.835 .806 \\
\hline \multicolumn{3}{|c|}{ Sumber $:$ Pengolah Data Excel } \\
\hline
\end{tabular}

Tabel 4. Analisa Nilai Rata-Rata Nilai Variabel Video Likes dan Video Views Akun Instagram Khloe Kardhasian

\begin{tabular}{|l|l|l|}
\hline No. & Video Likes & Video Views \\
\hline 1 & 235.660 & 2.323 .409 \\
\hline 2 & 1.156 .903 & 9.976 .549 \\
\hline 3 & 304.349 & 3.558 .831 \\
\hline 4 & 416.291 & 5.578 .949 \\
\hline 5 & 429.040 & 4.418 .247 \\
\hline 6 & 409.902 & 3.603 .441 \\
\hline 7 & 1.174 .456 & 6.748 .251 \\
\hline 8 & 324.566 & 2.809 .211 \\
\hline 9 & 640.748 & 8.237 .879 \\
\hline 10 & 549.614 & 8.405 .805 \\
\hline Total & 564.153 & 5.566 .057 \\
\hline
\end{tabular}

Sumber : Pengolah Data Excel 
Tabel 5. Analisa Nilai Rata-Rata Nilai Variabel Video Likes dan Video Views Akun Instagram Priyanka Copra Jonas

\begin{tabular}{|l|l|l|}
\hline No. & Video Likes & Video Views \\
\hline 1 & 1.103 .014 & 5.339 .113 \\
\hline 2 & 124.208 & 625.380 \\
\hline 3 & 521.913 & 2.789 .154 \\
\hline 4 & 605.764 & 4.377 .179 \\
\hline 5 & 400.828 & 2.566 .244 \\
\hline 6 & 927.379 & 4.516 .268 \\
\hline 7 & 546.914 & 3.442 .720 \\
\hline 8 & 598.046 & 3.672 .115 \\
\hline 9 & 432.710 & 3.735 .231 \\
\hline 10 & 294.503 & 2.408 .639 \\
\hline Total & 555.528 & 3.347 .204 \\
\hline
\end{tabular}

Sumber : Pengolah Data Excel

Setelah menghitung nilai rata-rata tersebut, maka akan menemukan hasil akhir nilai rata-rata dari variabel video Likes dan Video Views

Tabel 6. Nilai Variabel Pada Akun Instagram 5 Selebgram Perempuan di Dunia Dengan Bayaran Tertingi

\begin{tabular}{|l|l|l|r|r|r|}
\hline Variabel & $\begin{array}{l}\text { Selena } \\
\text { Gomez }\end{array}$ & $\begin{array}{l}\text { kylie } \\
\text { jenner }\end{array}$ & $\begin{array}{l}\text { khloe } \\
\text { khardashian }\end{array}$ & \multicolumn{1}{l|l}{$\begin{array}{l}\text { priyanka } \\
\text { copra Jonas }\end{array}$} & \multicolumn{1}{l|}{$\begin{array}{l}\text { Kendall } \\
\text { Jenner }\end{array}$} \\
\hline Video likes & 1640622 & 3839953 & 564153 & 555528 & 1980334 \\
\hline & & & & & \\
video views & 9660153 & 18835806 & 5566057 & 3347204 & 1510924400 \\
\hline
\end{tabular}




\section{Sumber : Pengolah Data Excel}

Pada akun Instagram terdapat 14 rasio yang relevan digunakan untuk mengukur kredibilitas pada masing-masing akun. Namun pada penelitian kali ini hanya berfokus untuk menghitung Video Likes to Video Views Ratio. Untuk menghitung kredibilitas dari masing-masing akun Instagram, peneliti menghitung dengan cara : variabel 1 akan dibagi dengan variabel 2 , sehingga ditemukan hasil analisisa dari rasio tersebut.

Tabel 7. Hasil Rasio Akun Instagram

\begin{tabular}{|l|l|l|l|l|l|}
\hline & $\begin{array}{l}\text { Kendall } \\
\text { jenner }\end{array}$ & $\begin{array}{l}\text { Selena } \\
\text { Gomez }\end{array}$ & $\begin{array}{l}\text { Khloe } \\
\text { khardashia } \\
\text { natio }\end{array}$ & $\begin{array}{l}\text { priyanka } \\
\text { Copra Jonas }\end{array}$ & $\begin{array}{l}\text { kylie } \\
\text { Jenner }\end{array}$ \\
\hline $\begin{array}{l}\text { video likes to } \\
\text { video views } \\
\text { Ratio }\end{array}$ & 0,131167779 & 0,169834272 & & & 0,2038 \\
& 3 & 5 & 0,101355951 & 0,165967775 & 64544 \\
\hline
\end{tabular}

Sumber : Pengolah Data Excel

Video Likes to Video Views Ratio memiliki karakteristik yang tinggi, artinya semakin tinggi nilai yang dihasilkan maka semakin baik kredibilitas dari performa akun tersebut. Untuk memberikan peringkat pada masing-masing Akun Instagram, peneliti memberikan angka 5 kepada Akun yang mendapatkan nilai tertinggi dan angka 1 untuk Akun Instagram yang mendapatkan nilai terendah. Berikut merupakan tabel urutan nilai yang dihasilkan oleh masingmasing Akun Instagram. 
Tabel 8. Nilai Rasio Akun Instagram 5 Selebgram Perempuan di Dunia Dengan Bayaran Tertinggi

\begin{tabular}{|c|c|c|c|c|c|}
\hline $\begin{array}{l}\text { Ratio } \\
\text { Video } \\
\text { Likes To } \\
\text { Video } \\
\text { views }\end{array}$ & $\begin{array}{l}\text { Kenddal } \\
\text { Jenner }\end{array}$ & $\begin{array}{l}\text { Selena } \\
\text { Gomez }\end{array}$ & $\begin{array}{l}\text { Khloe } \\
\text { Khardasian }\end{array}$ & $\begin{array}{l}\text { Priyanka Copra } \\
\text { Jonas }\end{array}$ & Kylie Jenner \\
\hline NIlai & 4 & 3 & & 1 & 5 \\
\hline
\end{tabular}

Dari Tabel Nilai Rasio Instagram Pada 5 Selebgram perempuan di Dunia Dengan bayaran Tertinggi dapat simpulkan bahwa Kylie Jenner mendapatkan nilai tertinggi untuk rasio Video Likes to Video Views. Sedangkan akun Instagram Priyanka Copra Jonas mendapatkan nilai terendah untuk rasio ini. Jadi, pada penelitian ini Kylie jenner memiliki kredibilitas performa yang lebih baik dibandingkan dengan Akun Instagram yang lainnya. 


\section{Kesimpulan}

Tujuan dari penelitian ini adalah mengetahui kredibilitas performa dari akun Instagram 5 Selebgram perempuan di Dunia Dengan bayaran Tertinggi menggunakan Video Likes to Video Views Ratio. 5 Selebgram perempuan di Dunia tersebut diantaranya : Kenndall Jenner, Selena

Gomez, Khloe Khardasian, Priyanka Copra Jonas, dan Kylie Jenner. Dari kelima Selebgram tersebut dapat disimpulkan bahwa :

1. Peringkat pertama diraih oleh Kylie Jenner dengan nilai tertinggi yaitu 0,203864544

2. Peringkat kedua diraih oleh Kenndall Jenner dengan nilai 0,1311677793

3. Peringkat ketiga diraih oleh Selena Gomez dengan nilai 0,1698342725

4. Peringkat keempat diraih oleh Khloe Khardasian dengan nilai 0,101355951

5. Peringkat kelima diraih oleh Priyanka Copra Jonas dengan nilai terendah yaitu 0,165967775 


\section{DAFTAR PUSTAKA}

Difika, F. (2016). Dakwah Melalui Instagram (Studi Analisis Materi Dakwah Dalam Instagram Yusuf Mansur, Felix Siauw, Aa Gym, Arifin Ilham). Walisongo Respository, 11-36. http://eprints.walisongo.ac.id/6462/

Ipa, P., \& Di, S. (2017). Title. http://scholar.unand.ac.id/33425/2/BAB 1 Pendahuluan.pdf

Mafulla, D., \& Kholik, A. (n.d.). Efektifitas Media Sosial Instagram Sebagai Strategi Promosi Online Kawasan Wisata Pacet Mojokerto. 1-8.

Yusuf. (2017). No Title. Metode Penelitian (Kuantitatif, Kualitatif, \& Penelitian Gabungan). https://books.google.co.id/books?id=RnA-

DwAAQBAJ\&printsec $=$ frontcover $\& \mathrm{hl}=\mathrm{id} \# \mathrm{v}=$ onepage $\& \mathrm{q} \& \mathrm{f}=$ false 